\title{
Leadership Style in TVET Education Towards 21st Century
}

\author{
$\mathrm{Sr} \mathrm{Hj}$. Mohd Fikri Bin Ismail \\ Director \\ Politeknik Sultan Mizan Zainal Abidin, \\ KM 8, Paka Road, 23000 Dungun, Terengganu, Malaysia \\ fikri@psmza.edu.my \\ Sharifah Nurulhuda Tuan Mohd Yasin. PhD \\ Department Of Information Technology \& Communication \\ Politeknik Sultan Mizan Zainal Abidin, \\ KM 8, Paka Road, 23000 Dungun, Terengganu, Malaysia \\ shnurulhuda@gmail.com
}

\begin{abstract}
Leadership is a critical aspect in organisation. As in $21^{\text {st }}$ century, it's shown that there are stiff competitions between giant companies to dominate the world economy. Literature shows that their secret of success depends on an open and innovative leadership. Academic leadership should be changed literally to tackle the globalization challenges, in line with technological advances. Leaders can be considered as a goalsetter, advocator, initiator, communicator, supporter, coordinator, coach, evaluator, manager, information provider and role model while implementing changes within the organisation. This study aims to identify leadership style in TVET education by $21^{\text {st }}$ century. The method used for the study is by analyzing and comparing the document with reference from previous review. Identification of theories that uphold leadership style will be the result of this study. This proves the connection between the theories used in this study.
\end{abstract}

Keywords : Leadership Style, TVET education, 21st century.

\section{INTRODUCTION}

Leadership is a communication and social interaction process that is often discussed by society latterly. It is an individual behaviour quality to achieve goals and organisational objective. Leadership can take place in a cluster or group. Obviously, the leader's behaviour and leadership style involve the influence of a chief towards his subordinates in that same cluster to achieve the planned objective. Leadership is the activity or art of a chief influencing others for the purpose of establishing cooperation with him in a cluster. In fact, leadership generally mean influence or a process to influence men so that they can cooperate voluntarily towards achieve common goals. Leadership style concerns on the approach used by a leader to sell his subordinate. Therefore, leadership style in one organisation is one of the factors which plays a significant role towards the increase of interest and individual in the organisation. So, a manager should own certain leadership style in administering the organisation (Glantz, 2012).

Lee \& Chuang (2019), said that an excellent leader not only started potential subordinate to improve efficiency but also need to have the qualifications in process achieving organisational goal. Many studies had shown that effective leader attitude can induce performance improvement when the organisation faces new challenges (McGrath \& MacMillan, 2000). Apart from that, leadership also reported to have close link forcefully. Every head should possess their own steady planning. He or she needs to have the power in leading direction. Thus, without a chief, the 
organisation may not work perfectly. Leadership style on the other hand, among others, depends on how far a leader have the role to decide structure task and organisation that led by him. Very important leadership style in creating satisfaction between employers and employee. In fact, effective style of leadership can inject close relationship between employers and employee in one organisation.

\section{Literature Review}

There are a few leadership style types in one organisation leadership theory. However, through this study, researcher only suggest three (3) leadership style type that always said by most researchers (Avolio \& Bass, 2002; Hassan \& Ismail, 2013). The leadership style type is Transformasional leadership, Autocratic and -Faire Laissez. All three leadership styles can be used in an organisation, however which is more suitable depends on the chief's situation, followers and working environment. Therefore, a leader that managed to use leadership style that is different for condition that is different. Appropriate style of leadership can enhance employee's motivation and morale while also creating positive working environment (Mohd Najib \& Tamyis, 2018).

Furthermore, a research by Laohavichien (2009) shows that Transformasional leadership is leadership that is having vision for quality management success. Nevertheless, Transaksional leadership or Autocratic does not reduce the quality practice. This coincide with a statement by Hassan \& Ismail (2013) which found that all dimension Transformasional leadership has positive and significant influences towards TQM practice in a few selected universities in Libya. In other studies, Berson and Linton (2005) have found that existence of significant positive relationship between leadership style with quality practice level in one organisation. Through this study, they find that Transformasional leadership and transactional contingency reward leadership drove organisation to environment direction.

In today's time, leadership became a pillar to educational institution success. An effective leader surely able to examine threat that exists and strive to change it to chance. This is parallel with the effort of running the country in accordance with Vision 2020. Former Prime Minister, Tun Mahathir (1996) had delineated a few leadership features that need to be owned by civilian administrators as 'main engine' that runs of the country. The intended features are to have a farsighted vision; able to decide objective; can evaluate followers' ability; capable of leading followers towards success. Based on various studies conducted before, several variables have been adopted in this study to measure employee performance. Leadership Democratic (lqbal et al., 2015), leadership autocratic (Akor, 2014; lqbal et al., 2015) and Laissez-faire leadership (Wang \& Huynh, 2013) has been adopted as an independent variable. Employee performance has been adopted as the dependent variable (Sean \& Hong, 2014; Malik, 2014). 


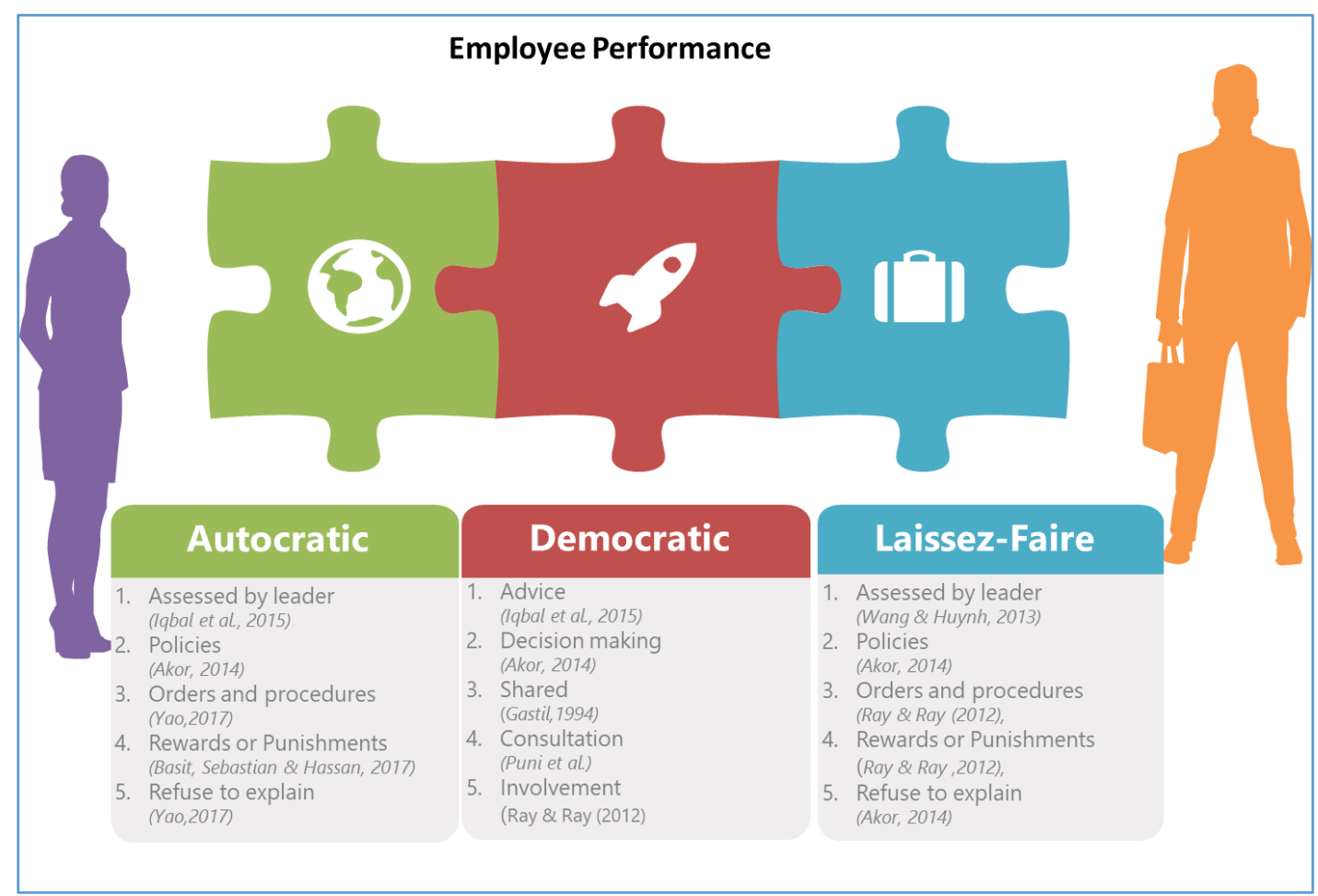

Figure 1. Conceptual Framework

\section{RESEARCH METHODS}

The purpose of this study is to identify leadership styles. To achieve this goal, this study is conducted qualitative in the form of analysis document. A few of previous survey report, conference proceeding, and journal had been referred as literature study, and analysed with data gathered use schedule matric (Strauss \& Corbin, 1990). According to Sallabas (2013) and Best \& Kahn (1998), method analysis document is the most suitable tool for collection of information in qualitative study. Apart from that, Onwuegbuzie et al. (2012)believe that variable related to the topic can be identified by doing research again towards literature study. This technique used, because it is method that is orderly to observe and evaluate document and electronic resource.

\section{RESULTS AND DISCUSSION}

\section{Leadership Styles}

To achieve an organisation's objective, a leader needs to be proactive through his leadership style effectiveness aspects towards employee. A leader is not necessarily a Director or someone who hold the top post in organisation; those who can influence organisation towards achieving the goal may also be classified as leader based on their ability to lead using intelligence, skill, experience, seniority level and so on . Leadership style in Fiedler study is personal relationship when a person give order, coordinate and oversee others in duty implementation. Leader manages cluster with one of the ways by telling people what to be done and how to make it or shared leadership responsibility with cluster members and involve them in duty 
implementation planning. Fiedler does not deny there are various postures between both leadership style but the basis for him is works motivate and coordinate group member carried out with two leadership style. This style can understand from someone's way evaluate his colleague that most disfavor him (Mohd Yusof, 1994).

This leadership theory idea has its root in interpersonal relationship theory. In his original study who checked relationship between therapist with his customer, Fiedler finds therapist that good his reputation inclined describe his patient as equal to himself. While that bad his reputation describe unequal patient with himself. This measure, called assumption equation (Mohd Yusof, 1994). Everyone leader own his leadership style respectively. Leadership style difference have a significant impact to productivity of individuals that they lead. According to Bahari (2009) there are a few leadership style for a leader.

\section{Autocratic}

Autocratic leadership style give priority to production and house profit organisation. In fact, autocratic leadership style also means a chief or employer that emphasize internal power administration. Not that only, employee also be made into platform to achieve objective that have been planned by chief. Some scholars inclined said leadership style as leadership directive. According to Yao et al., (2017) leader that is stylish more tend to make own decision compared to discuss with his subordinate. Employer which practice this leadership style reject to discuss with his subordinate. This employer is impersonal with his employee and only focused to task only. Autocratic leadership style shows a significant negative impact on employee performance. This indicates that performance of employees would increase when autocratic approach is applied note. Even though Malaysian leaders prefer and are most known to lead through autocratic leadership style, in the view of globalization, autocratic leadership style may no longer be accepted by employees who are now becoming more knowledgeable, independent and competent (Basit, Sebastian, \& Hassan, 2017).

A leader should be energetic move the subordinates do actions so that organisational purpose achieved. In effort move subordinates do whatever activity or job to achieve association's purpose, leader that is autocratic put his power in his own hand. The words or all needs cannot be objected. Others must obey and according to only in his will. Leader that is autocratic not behave guide; all injunctions should be well implemented. The decision is something best and should be meted without complain. Leader that autocratic give a lot of directives and all decisions only he alone that can make it. He regards that he alone can think for determining type activity that can be done by association. Members have not been given opportunity or opportunity to produce opinion or view, what else to together in making decision. They only received responsibility of implementing head's decision. In action run association, he rather use coercion and threat so that members feel afraid. Relationship between this type leader with society members not often nice or other word is too formal and full tension.

\section{Democratic}

Meanwhile, to democratic leadership style of a chief or employer give opportunity to his subordinate to get involved directly in his organisational administration system. Not that only, leader which practised this democratic leadership style also give opportunity to every his employee to give opinion and view before a decision taken. This democratic leadership is considerate more characteristic and hear more worker's view before deciding. Leader which practice democracy leadership style focus more on relationship between employers and 
employee in achieving something objective or organisational objective. Puni et al., (2014) stated that democratic leadership style centralised more on people and interaction is greater within the group. In democratic style, relationship between leader with persons led created in form of relationship humanity. Relationship between chief with subordinates based on principle mutual respect, cooperate and responsible. Everyone appreciated and respected as human, not as robot created only to implementing order. Leader that is democratic always giving opportunity to all members to give views, opinion and target for association good. Thereby, members will feel to be given attention until arise sense love and loyalty that are deep towards association and will always try to find the way to develop society.

Gastil (1994) proclaimed that democratic leadership influences people in a manner consistent with the basics of democratic principles and processes, such as deliberation, participation equal, inclusiveness and self-determination. Democratic leadership is leadership that active and his leader prepared accept comment or reprimand which built from team members. Therefore, all efforts carried out behoof with, namely for association interest, not for individual interest or a few individuals. All results taken for something activity is result achieved from negotiations and mutual agreement, not head's decision individually, but majority. Everyone will work earnestly and responsibly without feel the existence of pressure or coercion reason distribution of duties in democratic leadership is clear. Leader that is democratic not ruling but ask persons below him do something for mutual interest. He always strives for prioritize cooperation in efforts achieve association's purpose. According to Choi (2007), democratic leaders actively encourage and stimulate group decisions and group discussions. Ray \& Ray (2012), defined characteristic of democratic leaders as influential, helpful, knowledgeable, a good listener, encouraging, guiding, respecting and situation centered.

\section{Laissez-Faire}

Laissez-Faire leadership on the other hand bring meaning which a chief or employer like to give more fully freedom to his employee in decision-making, give opinion and / or take an action to determine organisation. Another objective side, this leadership style not emphasize performance or profit. This leadership style not also prioritize objective something the organisation. Leader or employer which practice this leadership style not set objective and objective that need to be aimed by his organisation. In fact, this style of leadership shows that a leader or employer has poor organisational management and lacks the confidence to be the leader in the organisation. Leader organisation that free to ignore only his group determine itself their all activities. This leader does not take certain attitudes towards his group. He does not guide or motivate the members, he does not control his association activity, even he do not like make decision. He only observe only what is done by his group. In other words, he as chief give freedom fully to persons led to make anything thought should.

This type leader named laissez-faire leader, namely leader that does not specify direction to persons under him. Freedom given indulges persons led. The position as chief only as symbol or "adviser" that only agree whatever proposal presented by downline because he himself dislike decide. By cause of the power exist in the chief is not clear, management and administration of association usually become stir. Every batch member move individually to achieve the personal target and not association goals or organisation. 


\section{CONCLUSOON}

Leadership is a life skill which need to achieve something organisation according to objective and objective with regard factors related. Every organisation needs leaders. Without a leader, an organisation cannot function properly. Indeed, the downfall of an organisation lies in the effectiveness of the leader's behavior and his leadership style in leading the organisation he leads (Akor, 2014). The outcome, through communication that is effective a chief can leverage on his subordinate to form a cluster that is dynamic to achieving organisation. Leadership objective is process by which an individual influence other member in his group towards achieve the purpose and group goal. In other words, leadership is process that much connected with influence, which a person the leader successfully influenced people below led to change attitudes and their behaviour (lqbal et al., 2015). A leader have techniques that able used by him to change attitudes and other behavior of people. Techniques used need not force people below to change. They influenced to change can still choose whether want to change or not want to change.

Leadership could not escape from leader concept and follower. Without follower so does not happen leadership. Every leader be his follower that give loyal to their leaders. Hal directly related with characteristics of leader that is readily acceptable by follower. Leader with simple features liked by downline facilitate those influence people below change attitudes, thinking and their behaviour (Lee \& Chuang, 2019). This role of leader is very large to one organisation or group. This leader function create vision and organisation mission and create strategies to achieve it. These leaders determine direction course. In future of organisation needs leader. Without one organisation leader cannot perfectly functioning. This is because rise and fall him one organisation depend on leader. A leader said managed to if he successfully mould leadership that right in his organisation. An organisation's success depends on support and praise of all members. To become capable leader, a person not only need to having knowledge and experience, but also had to work for build internal power more than physical strength. Force of strength intended is strength to control, influence, persuade, force confirm, and force make reference.

Ray \& Ray (2012) says the effectiveness of a leader can be said depend on several factors like leader's self-nature itself, organisation internal situation, and also factors which affect staff behaviour. Organisational excellence depends on leadership with vision because able give priority that focusing to mankind and vision. Leader that successfully implemented leadership function by building organisation vision can make big increase organisational goal and able realize organisational goal. Clarity of vision, insight into knowledge, enthusiasm towards vision, perseverance and dedication to vision, global view, ability to believe in organisational effectiveness and paradigm partnership can improve employee satisfaction. Altogether show leader's success and employee realise organisational goal. Although leadership can be learned, but not all people can be leader that good. Becoming good guide requires patience, perseverance, learning that continued, attitude love knowledge, mastery of various skills, high self-discipline, readiness to receive criticism also criticism and so on. The outcome a organisation leader that good not only depend on post held but more to his capacity run roles in organisational effectively and control skills well expressed. 


\section{ACKNOWLEDGEMENTS}

This research paper has been funded by Politeknik Sultan Mizan Zainal Abidin, Ministry of Education, Malaysia

\section{REFERENCES}

Akor, P. U.. Influence of Autocratic Leadership Style on the Job Performance of AcademicLibrarians in Benue State. Journal of Educational and Social Research, 4(7), 148-152. (2014).

Avolio, B. J., \& Bass, B. M.. Developing potential across full range of leadership. Erlbaum Associates.

Bahari, A. (2009). Menjadi pemimpin. Qarya Sdn. Bhd. (2002)

Best, J. W., \& Kahn, J. V.. Research in Education. (Edisi ke-8). Allyn and Bacon. (1998)

Choi, S.. Democratic Leadership: The Lessons of Exemplary Models for Democratic Governance. International Journal of Leadership Studies, 2(3), pp. 243-262. International Journal of Leadership Studies, 2(3), 243-262. (2007)

Gastil, J.. A Definition and Illustration of Democratic Leadership. Human Relations, 47(8), 953975. (1994)

Glantz, J. Finding your leadership style. A Guide for educators; Association for supervision and curriculum development. (2012).

Hassan, A. A., \& Ismail, A.. The influence of transformational leadership on the level of TQM implementation in the higher education sector. Higher Education Studies. 3(1). https://doi.org/ISSN 1925-4741(2013)

lqbal, N., Anwar, S., \& Haider, N. Effect of Leadership Style on Employee Performance. Arabian Journal of Business and Management Review, 5(5), 1-6. (2015).

Lee, \& Chuang.. The impact of leadership styles on Job stress and turnover intention: Taiwan Insurance Industry as an example. www.hclee@ttu.edu.tw(2019)

McGrath, G. ., \& MacMillan, I. C.. Entrepreneurial Mindset: Strategies for continuously creating opportunity in an age of Uncertainty. Harvard Business School Press Books. (2000)

Mohd Yusof, A. Kepimpinan. : Dewan Bahasa dan Pustaka. (1994).

Onwuegbuzie, A. J., Leech, N. L., \& Collins, K. M. T.. Qualitative analysis techniques for the review of the literature. (17th ed.). (2012)

Puni, A., Ofei, S. B., \& Okoe, A. The Effect of Leadership Styles on Firm Performance in Ghana. International Journal of Marketing Studies, 6(1), 177-185. (2014).

Ray, S., \& Ray, I. A. Understanding Democratic Leadership: Some Key Issues And Perception With Reference To India's Freedom Movement. Afro Asian Journal of Social Sciences, 3(1), 1-26. (2012).

Sallabas, M. E.. Analysis of narrative texts in secondary school textbooks in terms of values education. Educational Research and Reviews, 8(8): 361-366. doi:10.5897/ERR12.190. Educational Research and Reviews, 8(8), 361-366. https://doi.org/10.5897/ERR12.190. (2013)

Strauss, A., \& Corbin, J. Basics of qualitative research: Grounded theory procedures and techniques. CA: Sage. (1990).

Yao, L., Woan, K. S., Li, F., \& Ahmad, M. H. The Relationship between Leadership Styles and Employee Engagement: Evidences from Construction Companies in Malaysia. The Social Sciences, 6(12), 984-988. (2017). 